Discourse and Communication for Sustainable Education, vol. 12, no. 1, pp. 102-120, 2021

\title{
The Effect of Sustainable Leadership Behaviors of School Principals on Teachers' Organizational Commitment and Job Satisfaction
}

\author{
Semih Çayak \\ Ministry of National Education, Istanbul, Turkey
}

\begin{abstract}
Sustainable leadership is a field of research in which a lot of research has been done recently. In this study, the effects of sustainable leadership behaviors of school principals on teachers' organizational commitment and job satisfaction were examined based on teachers' opinions. The sample of the study consists of 338 teachers working in three districts of Istanbul. Sustainable Leadership Scale, Organizational Commitment Scale and Job Satisfaction Scale were used in the research. Research data were analysed by arithmetic mean, standard deviation, correlation analysis and stepwise regression analysis. According to the findings, teachers' organizational commitment, job satisfaction, and their perceptions regarding sustainable leadership behaviors of school principals were found to be at a high level. As a result of the stepwise regression analyses, the economic sustainability sub-dimension of the sustainable leadership scale was found to predict teachers' job satisfaction. On the other hand, it was determined that the managerial and social sustainability sub-dimensions significantly predicted teachers' organizational commitment. The findings obtained were discussed in the light of the related literature and suggestions were presented.
\end{abstract}

Key words: sustainable leadership, organizational commitment, job satisfaction, school principal, primary school

\section{Introduction}

The concept of sustainability, which is used in different disciplines, has a wide application area (Salite et al., 2016; Salite et al., 2020; Heasly et al., 2020) and is based on the idea that "less capital or resources should be consumed compared to the produced" (Ehnert, Harry, \& Zink, 2014). Sustainability is an interdisciplinary field that requires cooperation from more than one perspective (Cohen, DeFrancia, \& Martinez, 2016; Eskici, 2019). As a matter of fact, sustainability has become an important issue in economic, technological, political and organizational levels, rather than being a concept that belongs only to the ecological field (Borland, Ambrosini, Lindgreen, \& Vanhamme, 2016). In this respect, when sustainability is examined in an organizational context, organizations and leaders should think beyond short-term profits and try to ensure the 
long-term survival of the organization; in other words, they must be sustainable (McCann \& Sweet, 2014). To achieve this goal, sustainable leaders are needed to ensure sustainability in organizations (Hargreaves \& Fink, 2006). Sustainable leadership is a shared responsibility that does not unnecessarily consume human and financial resources and avoids harming them (Ghosh \& Chatterjee, 2014, p. 166).

Sustainability is the founding principle of sustainable leadership, and definitions on sustainable leadership emphasize many features and aspects that support the concept (Gerard, McMillan, \& D'Annunzio-Green, 2017). As stated in Balc1 (2010) sustainability is an innovation or practice that becomes long term and institutionalized. Therefore, sustainable organizations are expected to create benefits for their stakeholders while protecting the environment and developing their own lives (Schwalb, 2011). For this reason, sustainable leaders are expected to ensure that members of the organization stay in their organizations and get satisfaction from their work (Cetin \& Cayak, 2018).

Organizations are facing a wide range of challenges due to increasing globalization pressure, developing technology, international competition, changing business relations, and increasing workforce diversity. In such an environment, the organization employees undoubtedly have great responsibilities in organizations' attaining their goals and achieving success (Agarwa \& Sajid, 2017). This is because organizations can achieve the success, they desire in the field they operate with their qualified labor force and maintain their organizational existence. Therefore, qualified employees who are committed to the organization they work for and are satisfied with their work are of vital importance for organizations to succeed (Mowday, Steers, \& Porter, 1998; Jaramillo, Mulki, \& Marshall, 2005; Kelidbari, Dizgah, \& Yusefi, 2011).

Employees may leave the organization from time to time for many different reasons, such as insufficient wages, not getting the desired satisfaction from the job, and not being able to feel a sense of commitment to the organization, thus filling the gap they left in the organization is not that easy. For this reason, the biggest expenditure faced by most organizations trying to retain their qualified labor force is the labor cost in the form of highly qualified, innovative, and competitive employees for the long-term success of the organization (Frese \& Fay, 2000). Employees who have low job satisfaction and are not committed to their organizations are those who tend to make mistakes in their jobs, tend to be absent and to experience stress, and have more intention to leave work (Agarwa \& Sajid, 2017). Because leadership is the basic element of educational institutions, leadership is becoming more and more important in today's education system (Munir \& Iqbal, 2018).

At this point, it is thought that the leadership behaviors of the organization managers will be effective in increasing the loyalty and satisfaction of the employees regarding the organization, especially in terms of the continuity of the organizational activities and workforce and the employees' delivering their performance in the best way.

In line with the issues mentioned above, it is thought that organization managers' exhibiting sustainable leadership behaviors that require taking a long-term perspective in making decisions, promoting systematic innovation aimed at increasing customer value, developing qualified, loyal and highly intense workforce and providing quality products, services and solutions (Avery \& Bergsteiner, 2011, p. 5), will be effective in increasing organization employees' organizational commitment and job satisfaction. The new type of paradigm in leadership is directed towards sustainable leadership, which is characterized by three main processes: "learning by doing", "awareness of 
personal goals and personal assumptions and motivations" and "knowing how to manage stress and adequate care effectively” (Casserley \& Critchley, 2010).

There are many studies in the literature that examine the organizational commitment and job satisfaction of employees as well as the relationship between these two concepts and the different leadership behaviours exhibited by organization managers. However, there is no study in the literature examining the effect of sustainable leadership behaviors of organization managers on employees' organizational commitment and job satisfaction. Based on these factors, in this research, the effects of sustainable leadership behaviors exhibited by school principals on teachers' organizational commitment and job satisfaction were investigated in order to achieve the desired success in schools, where training activities, which are among the most important driving forces of social development, are performed. In this regard, it is known that teachers who are satisfied with their jobs and who have a high commitment to the institution they work for are more willing and devote more energy and time to increase their students' success (Kennerly, 1989; Patrick, 2007; Banjarnahor, Hutabarat, Sibuea, \& Situmorang, 2018). Therefore, it is difficult to expect teachers who are not satisfied with their jobs and who have low commitment to the institution they work for to be fully beneficial to their students. For this reason, it is believed that sustainable leadership behaviors of school principals, who play a very important role in determining the quality of education in schools, will positively affect teachers' organizational commitment and job satisfaction and contribute to teachers' fulfilling their duties effectively and efficiently.

\section{Conceptual Framework}

\section{Organizational Commitment}

Organizational commitment, which is a psychological phenomenon regarding the employee's relationship with the organization and which reduces the employee's intention to leave the organization (Allen \& Meyer, 2000), has been one of the most researched and important topics in organizational psychology due to its potential effects on the organization and its employees (Mowday, Steers, \& Porter, 1998; Kaul \& Singh, 2017). The concept of organizational commitment, which was first introduced to the organizational literature by Becker in 1960, later became a topic that many researchers investigated. Meyer and Allen are among the leading researchers who have made significant contributions to the organizational commitment literature. The three-dimensional organizational commitment model developed by Meyer and Allen (1991) is still one of the most used organizational commitment models today. In this model, organizational commitment of employees is examined in three dimensions, emotional commitment, continuance commitment and normative commitment. In emotional commitment, employees pursue their membership in the organization because they have an emotionally strong commitment to the organization, and they want it. Continuance commitment is the awareness of the costs associated with leaving the organization. Employees with a strong continuance commitment pursue working in the same organization because they think that job switch will have a high changing cost. Normative affiliates continue to serve due to the compulsory feelings they have for their organizations. Employees with high normative commitment continue their membership in the organization if they deem it necessary (Meyer \& Allen 1997; Imran \& Binti Aziz, 2017). 


\section{Job Satisfaction}

Job satisfaction is one of the organizational variables in which a lot of researchers have been carried out in the field of organizational behavior and has far-reaching effects for both employees and the organization (Spector, 1997; Agarwa \& Sajid, 2017). Job satisfaction (Baba, 2017), which is a vital quality that allows an employee to reach his/ her maximum capacity, is considered a critical component of corporate success (Bilyalov, 2018). Job satisfaction is a psychological atmosphere that does not have a universal standard dimension valid for everyone (Banjarnahor et al., 2018). Therefore, the fact that job satisfaction involves a subjective process also makes it difficult to define (Lizote, Verdinelli, \& Nascimento, 2017). For the first time in 1935, Happack defined the concept of job satisfaction as "a combination of psychological, physiological and external conditions that express a person's satisfaction with his/her job" (as cited in Hussain \& Soroya, 2017). Spector (1997), on the other hand, defined job satisfaction as "the degree of people's like (satisfaction) or dislike (dissatisfaction) with their jobs."

In this context Herzberg (1987) developed a motivational theory in which structures that affect an employee's job satisfaction are classified in two areas. These are motivation tools (intrinsic factors) and hygiene (extrinsic factors). Motivating factors are intrinsic factors that include elements such as success, recognition, the job itself, responsibility and progress; on the other hand, hygiene or extrinsic factors include wage, job security, working conditions, supervision and interpersonal relationships. In general, intrinsic job satisfaction is how people feel about the nature of their job duties, and extrinsic job satisfaction is how people feel about the aspects of their employment status. Therefore, managers are recommended to develop strategies to increase both intrinsic and extrinsic job satisfaction levels of employees (Tepayakul \& Rinthaisong, 2018).

\section{Sustainable Leadership}

The sustainability interpretations are available in contexts of different scientific spheres: economics, ecology, psychology, philosophy, art and social sciences (Akyar \& Sapsağlam (2019). One of the areas where sustainability is related is leadership. Hargreaves and Fink (2003, p. 2), who are among the leading researchers who set forth the first studies in the field of sustainable leadership, defined sustainable leadership as "one of the key forces that affect change or continuity in the long run." In fact, as Avery and Bergsteiner (2011, p. 5) state, sustainable leadership requires taking a long-term perspective in making leadership decisions, promoting systematic innovation aimed at increasing customer value, development of a qualified, loyal and highly intense workforce and providing quality products, services and solutions. From an educational point of view, sustainable leadership is described as "one of the key factors" underlining the longterm development of the school, and it is stated that sustainable leadership promotes a culture of leadership based on the moral purpose of the school, and this provides a success that everyone can achieve (Davies, 2007, pp. 2-3). Therefore, sustainable education leadership is not self-focused. It believes in cohesion, collaboration and learning and participates in social formation (Hargreaves \& Fink, 2003, p. 8).

An effective sustainable leadership behavior can only emerge when there are friendly and collaborative behavior interactions between team members (Jahanshahi \& Brem, 2017, p. 3). This depends on the commitment felt throughout the organization and the 
indisputable effectiveness and development of the internal environment for the development and achievement of sustainable leadership. Collective work, commitment and unobstructed communication are important elements in ensuring successful teamwork (Gereard, McMillans, \& D’Annunzio-Green, 2017).

Schools are constantly changing; students, families, community, expectations and the content of the functions of schools are continually changing (Blackburn \& Williamson, 2018 , p. 8). In this respect, sustainable leadership theory teaches leaders to look at external forces that can affect the school from inside and outside by providing some principles to help school leaders pursue school reforms. Thus, school leaders learn to cope with problems in a holistic way and recognize their school's interdependence with other institutions and their influence on each other (Mourkogiannis, 2005). Stating that sustainable leadership is one of the key factors that underlines the long-term development of the school and creates a leadership culture based on a moral goal that provides a success that everyone can achieve, Davies (2007, p. 3) described the main principles of sustainable leadership in the leadership model, which he termed "Nine Key Factors", as follows: Measuring outcomes and not just outputs, Balancing short and long term objectives, Thinking in terms of processes, not plans (the way leaders involve their colleagues is more important than the documents they write), having a passion for continuous improvement and development, developing personal humility and professional will as a means of building long-term leadership capacity, practising strategic timing and strategic abandonment, building capacity and creating involvement, developing strategic measures of success, building in sustainability.

According to Hargreaves and Fink (2006, p. 20), who suggest that the goal of leadership in sustainability is to build schools, reliable communities and professional learning communities that share knowledge, the principles of sustainable leadership are:

1. Depth: Sustainable leadership is important.

2. Duration (Length): Sustainable leadership is ongoing.

3. Breadth: Sustainable leadership spreads.

4. Justice: Sustainable leadership does not actively harm the environment.

5. Diversity: Sustainable leadership promotes diversity.

6. Resourcefulness: Sustainable leadership improves human and material resources instead of consuming them.

7. Conservation: Sustainable leadership is honored by and learns from the best of the past to create a better future.

\section{The Relationship Between Sustainable Leadership, Organizational Commitment and Job Satisfaction}

That education systems work efficiently and that their goals are achieved in the best way undoubtedly depend on all education stakeholders' fulfilling their duties and responsibilities effectively (Akar, 2018). For this reason, the psychological functioning of teachers, who are one of the most important elements of the educational process, has emerged as an important issue/case for educators, students and schools worldwide (Collie, Granziera, \& Martin, 2018).

Organizational commitment and job satisfaction are among the most important business-related attitudes studied in the field of management and organizational behavior 
(Allen \& Meyer, 2000; Agarwa \& Sajid, 2017). In a meta-analysis performed by Meyer et al. (2002), it was found that a satisfied and happy employee is more committed to the organization. Therefore, the fact that teachers are satisfied with their jobs and have a sense of commitment to their organization to be successful are considered as an indicator in determining the success of the school (Banjarnahor et al., 2018). It is believed that teachers will feel more commitment to the school with the sustainable leadership behaviors that the principals responsible for the management of the school will display. In addition, the leadership style of an organization and his/her subordinates' job satisfaction are positively related (Yousef, 2000; Chen \& Silverthorne, 2005; Reza, 2013). For these reasons, principals are considered an important force for school success (Leithwood \& Seashore-Louis, 2011). School principals increase teachers' job satisfaction with multidimensional roles they play in schools (Kennerly, 1989; Northouse, 2007). Thus, they render them more useful to their students (Munir \& Iqbal, 2018).

One of the most important features of sustainable leaders is that they ensure social sustainability in their institutions. A socially sustainable system is a system that can ensure the distribution of social services, including health, education, gender equality, political responsibility and participation, equally and adequately (Harris, 2000, p. 6). In other words, a socially sustainable organization is an organization, the members of which adopt the values and norms of the organization and feel that they belong to the organization, where an open communication system is created within the organization, the members of the organization can easily express themselves and the employees feel valuable. Accordingly, Eccles, Ionnoau and Serafeim (2012, p. 25) who stated that creating a sustainability culture in an organization has some benefits, emphasized that increase in the performance and commitment of the employee are some of these benefits. Since schools are among the most important organizations in the communities and people are the most essential output of educational institutions, it is necessary to investigate teachers' organizational commitment (Baba, 2017) and job satisfaction (Rezaee, Khoshsima, Zare-Bahtash, \& Sarani, 2018), which are among the factors that can affect their job performance. Teachers as agents of societal change (Iliško, 2007), who are among the most important stakeholders of the schools, and have great responsibilities in the realization of social development, their professional commitment to the institution they work in and their job satisfaction are crucial for them to show the highest performance in their jobs and to be beneficial to their students. As a matter of fact, it would not be right to expect a teacher who does not feel any commitment to the school s/he works for and cannot get satisfaction from his/her job, to fulfill his/her duty with all his/her energy.

\section{The Aim of the Study}

The aim of this research is to examine the extent to which teachers' organizational commitment and job satisfaction are predicted by the school principals' sustainable leadership behaviors. To this end, answers to the following questions were sought.

1) What are the sustainable leadership behavior levels of school principals, organizational commitment levels of teachers and teachers' job satisfaction levels according to the perceptions of teachers?

2) Do the school principals' sustainable leadership behaviors predict teachers' organizational commitment and job satisfaction? 


\section{Method}

This study, which examines the impact of school principals' sustainable leadership behaviors on teachers' organizational commitment and job satisfaction, utilised a relational survey model, which is one of the quantitative research models.

\section{Sample}

The population of the research consists of 2595 class teachers who work in 78 public primary schools in Beylikduzu, Zeytinburnu and Pendik districts of Istanbul in 2018-2019 academic years. Yazıcioglu and Erdogan (2004, p. 50) report that it is sufficient that the sample, which can represent the population within the range of 2500 5000 with $5 \%$ error rate on the sample determination sample is within the range of 333-357. 25 primary schools targeted to be reached in the study were determined by proportional cluster sampling method considering the number of public primary schools in the districts (Pendik $=14$ primary schools, Beylikduzu $=6$ primary schools and Zeytinburnu $=5$ primary schools). 338 scales returned from the scales distributed to teachers in these schools were determined to be suitable for data analysis. 207 (61\%) of the 338 teachers who make up the sample group are females and $131(39 \%)$ are males.

\section{Data Collection Tools}

In the research, the Sustainable Leadership Scale developed by Cayak and Cetin (2018), the short form of Minnesota Job Satisfaction Scale, which was developed by Weiss, Dawis, England and Lofquist (1967) and translated into Turkish by Baycan (1985), and whose validity and reliability study was performed, and the Organizational Commitment Scale developed by Meyer, Allen and Smith (1993) and adapted to Turkish by Daglı, Elcicek and Han (2018) were used. The psychometric properties of the data collection tools are presented below.

\section{Sustainable Leadership Scale}

The Sustainable Leadership Scale, which aims to measure the sustainable leadership behavior levels of school principals according to the perceptions of teachers, is a 5 -point Likert type scale consisting of 4 sub-dimensions and 36 items. The 36 items, the factor loads of which range from .55 to .79 , explain $66.71 \%$ of the total variance. The goodness of fit values obtained as a result of confirmatory factor analysis regarding the fourfactor structure of the scale are as follows: $\mathrm{X}^{2} / \mathrm{df}=3.55 ; \mathrm{TLI}=.91, \mathrm{CFI}=.92$ and RMSEA $=.06$. Cronbach's Alpha internal consistency coefficients calculated for the sub-dimensions and overall, of the scale were found to be .97 for the Managerial Sustainability sub-dimension, .92 for the Economic Sustainability sub-dimension, .85 for the Cultural Sustainability sub-dimension, .87 for the social sustainability sub-dimension and .98 for the overall scale. 


\section{Minnesota Job Satisfaction Scale}

The short form of Job Satisfaction Scale, which aims to measure teachers' job satisfaction levels, is a 5-point Likert-type scale consisting of 2 sub-dimensions and 20 items. The validity and reliability tests of the scale were performed by Baycan (1985) and the Cronbach's Alpha value was found to be 0.77 . In the research conducted by Zeynel (2014) the Cronbach's Alpha internal consistency coefficients calculated for the sub-dimensions of the scale and for the overall scale were found to be 0.78 for the internal factors, 0.72 for the external factors and 0.83 for the overall scale. The goodness of fit values obtained as a result of confirmatory factor analysis regarding the twofactor structure of the scale are as follows (Zeynel, 2014): $\mathrm{X}^{2} / \mathrm{df}=3.59$; GFI $=.89$ and $\mathrm{AGFI}=.87 ; \mathrm{RMR}=.07 ; \mathrm{NFI}=.90 ; \mathrm{CFI}=.91 ; \mathrm{IFI}=.91$.

\section{Organizational Commitment Scale}

The Organizational Commitment Scale, which aims to measure teachers' organizational commitment levels, is a 5-point Likert-type scale consisting of 3 sub-dimensions and 18 items. The validity and reliability tests of the scale were developed by Meyer, Allen and Smith (1993) and adapted to Turkish by Dagl, Elcicek and Han (2018). The 18 items, the factor loads of which range between .33 and .80 explain $52 \%$ of the total variance. The goodness of fit values obtained as a result of confirmatory factor analysis regarding the three-factor structure of the scale are as follows: $\mathrm{X}^{2} / \mathrm{df}=2.104$; CFI $=.90$ and RMSEA $=.070 ; \mathrm{GFI}=.88 ; \mathrm{AGFI}=.84 ; \mathrm{NFI}=.83$. Cronbach's Alpha internal consistency coefficients were found to be .80 for emotional commitment, .73 for continuance commitment, .80 for normative commitment, and .88 for the overall scale.

\section{Procedures and Data Analysis}

Data collection tools were distributed to 500 teachers who voluntarily participated in the research by the researchers. 48 scales that were found to be missing or incomplete from 386 scales filled in by the participants and returned were not included in the analysis. Thus, 338 scales were included in the analysis. Data collected from 338 teachers were analysed using SPSS 22.0 program. Firstly, whether the data met the one-way and multi-faceted normality assumptions was examined. In line with this purpose, the skewness-kurtosis values and Q-Q graphs of the data set were examined. It was concluded that scores were within the limits of normal distribution. George and Mallery (2003) and Kunnan (1998) state that the data show normal distribution in case the skewness and kurtosis coefficients are within the range of \pm 2 , and Kalayc1 (2010) states that the distribution meets the normality assumption in case the skewness and kurtosis values are within the range of \pm 3 ( \pm 2 according to some authors). In addition, it was seen that the expected and realized values of the data formed on Q-Q graphs were distributed close to a line with a slope of 45 degrees. Therefore, this situation shows that the distribution of the data will be accepted as normal (Can, 2014). Since multivariate analyses were used in the study, whether there is a multiple connection problem between variables was also examined. In line with this purpose, the correlation values between the variables were calculated. Among the predictor variables, a correlation above .80 indicates that there might be a multiple connection problem, and a correlation above .90 indicates 
that there may be an important multiple connection problem (Buyukozturk, 2011). Based on this information, as can be seen in Table 1, there is no multiple connection problem between sub-dimensions. In the analyses, the significance of the difference between mean scores was found to be at the level of .05. In the interpretation of arithmetic mean, the range 1.00-1.79 was considered "very low", the range 1.80-2.59 "low", the range 2.60-3.39 "medium", the range 3.40-4.19 "high" and the range 4.20-5.00 "very high". Descriptive statistics, correlation and stepwise regression analysis were used to analyse the data.

\section{Findings}

Regarding the sub-dimension scores of the scales used in the research, the relations between arithmetic mean, standard deviation, and skewness-kurtosis values and the sub-dimension scores of the scales used in the study are presented in Table 1.

\section{Table 1}

Descriptive Statistics of the Variables and Correlation Analysis Findings

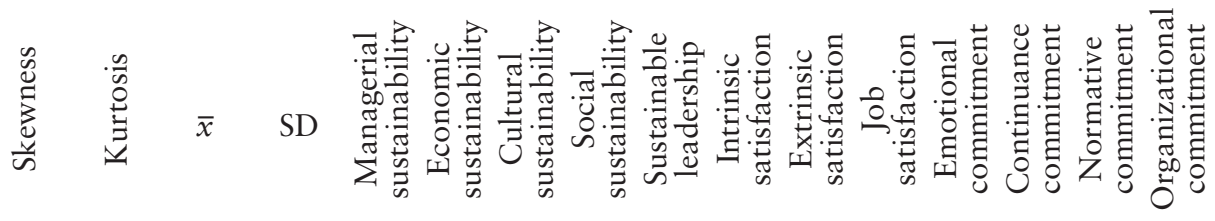

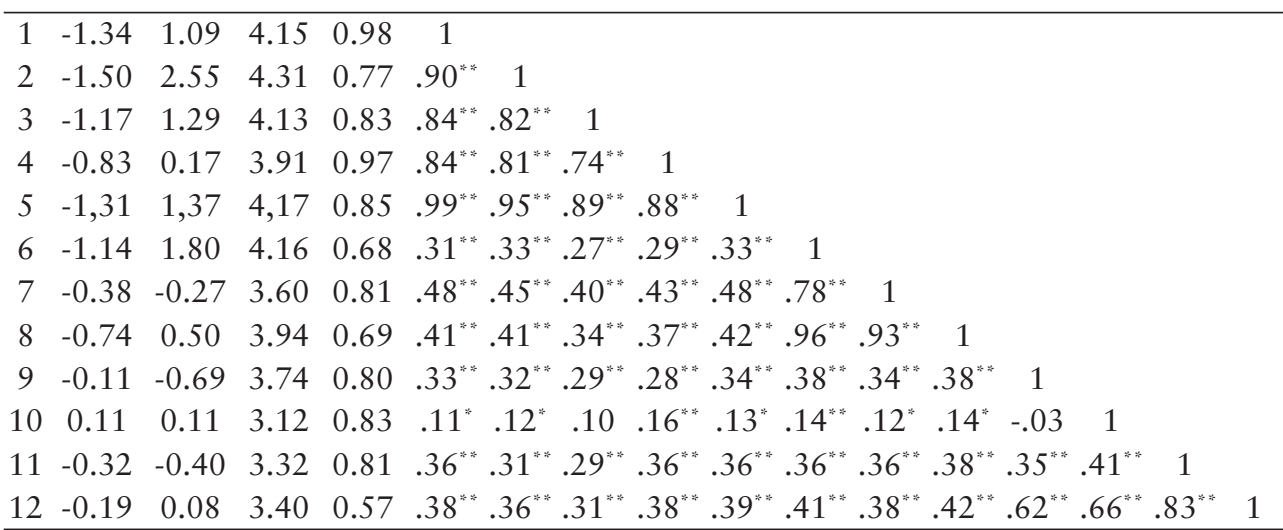

$* p<.05, * p<.001 ; N=338$

When Table 1 is examined, the perceptions of teachers regarding the sustainable leadership behaviors of school principals $(\bar{x}=4.15)$ the job satisfaction of teachers $(\bar{x}=3.94)$ and the organizational commitment of teachers $(\bar{x}=340)$ were found to be at a high level. The predictive power of the relationship between predictor variables and predicted variables, which have a significant relationship, was investigated by stepwise multiple regression analysis. The stepwise regression analysis on the intrinsic satisfaction, which is the first sub-dimension of the job satisfaction scale, is presented in Table 2. 


\section{Table 2}

Results of Stepwise Regression Analysis on the Prediction of Intrinsic Satisfaction

\begin{tabular}{cccccccccc}
\hline Model & $\mathrm{B}$ & Std. Error & $\beta$ & $\mathrm{t}$ & $\mathrm{p}$ & $\mathrm{R}$ & $\mathrm{R}^{2}$ & $\mathrm{~F}$ & $\mathrm{p}$ \\
\hline Constant & 2.90 & .20 & & 14.63 & .000 & & & & \\
Economic S. & .29 & .045 & .33 & 6.49 & .000 & .33 & .11 & 42.15 & .000 \\
\hline
\end{tabular}

The ANOVA table regarding the stepwise regression analysis showed that the described regression model was statistically significant. As can be seen in Table 2, since the stepwise regression analysis did not significantly predict the intrinsic satisfaction sub-dimension of the job satisfaction scale, it did not include the managerial, social and cultural sustainability variables in the analysis and the economic sustainability variable was treated in the stepwise regression analysis process. The economic sustainability sub-dimension explains $11 \%$ of the total variance regarding intrinsic satisfaction $\left[\mathrm{F}_{(1.336)}=42.15\right.$; $\mathrm{p}<0.001$ ]. According to Cohen (1988; as cited in Ozsoy and Ozsoy, 2013, p. 339), the effect size results are as follows $\left(\mathrm{R}^{2}\right)$ : .0196 is stated as small effect value, .1300 as moderate effect value, and .2600 as large effect value. Therefore, it can be said that the $\mathrm{R}^{2}$ value $\left(\mathrm{R}^{2}=.11\right)$ obtained in this analysis has a small effect size.

The stepwise regression analysis on extrinsic satisfaction, which is the second subdimension of the job satisfaction scale, is presented in Table 3.

\section{Table 3}

Results of Stepwise Regression Analysis on the Prediction of Extrinsic Satisfaction

\begin{tabular}{cccccccccc}
\hline Model & $\mathrm{B}$ & Std. Error & $\beta$ & $\mathrm{t}$ & $\mathrm{p}$ & $\mathrm{R}$ & $\mathrm{R}^{2}$ & $\mathrm{~F}$ & $\mathrm{p}$ \\
\hline Constant & 1.96 & .170 & & 11.58 & .000 & & & & \\
Managerial S. & .40 & .04 & .48 & 10.02 & .000 & .48 & .23 & 100.48 & .000 \\
\hline
\end{tabular}

The ANOVA table regarding the stepwise regression analysis showed that the described regression model was statistically significant. As can be seen in Table 3, since the stepwise regression analysis did not significantly predict the extrinsic satisfaction sub-dimension of the job satisfaction scale, it did not include the managerial, social and cultural sustainability variables in the analysis and only the managerial sustainability variable was treated in the stepwise regression analysis process. Managerial sustainability explains $23 \%$ of the variance related to extrinsic satisfaction $\left[F_{(1.336)}=100.48 ; \mathrm{p}<0.001\right]$. It may be asserted that the resulting $\mathrm{R}^{2}$ value $\left(\mathrm{R}^{2}=.23\right)$ has a moderate effect size.

The stepwise regression analysis on the overall job satisfaction scale is presented in Table 4.

\section{Table 4}

Results of Stepwise Regression Analysis on the Prediction of Job Satisfaction Scale (Overall)

\begin{tabular}{cccccccccc}
\hline Model & $\mathrm{B}$ & Std. Error & $\beta$ & $\mathrm{t}$ & $\mathrm{p}$ & $\mathrm{R}$ & $\mathrm{R}^{2}$ & $\mathrm{~F}$ & $\mathrm{p}$ \\
\hline Constant & 2.36 & .19 & & 12.16 & .000 & & & & \\
Economic S. & .37 & .04 & .41 & 8.25 & .000 & .41 & .17 & 68.04 & .000 \\
\hline
\end{tabular}


The ANOVA table regarding the stepwise regression analysis showed that the described regression model was statistically significant. As can be seen in Table 4, since the stepwise regression analysis did not significantly predict the overall job satisfaction scale, it did not include the managerial, social and cultural sustainability variables in the analysis and only the economic sustainability variable was treated in the stepwise regression analysis process. Economic sustainability accounts for about $17 \%$ of the variance for the overall job satisfaction scale $\left[\mathrm{F}_{(1.336)}=68.04 ; \mathrm{p}<0.001\right]$. It may be asserted that the resulting $\mathrm{R}^{2}$ value $\left(\mathrm{R}^{2}=.17\right)$ has a moderate effect size. The stepwise regression analysis on emotional commitment, which is the first sub-dimension of the Organizational Commitment Scale, is presented in Table 5.

\section{Table 5}

Results of Stepwise Regression Analysis on the Prediction of Emotional Commitment

\begin{tabular}{cccccccccc}
\hline Model & $\mathrm{B}$ & Std. Error & $\beta$ & $\mathrm{t}$ & $\mathrm{p}$ & $\mathrm{R}$ & $\mathrm{R}^{2}$ & $\mathrm{~F}$ & $\mathrm{p}$ \\
\hline Constant & 2.60 & .18 & & 14.40 & .000 & & & & \\
Managerial S. & .27 & .04 & .33 & 6.48 & .000 & .33 & .11 & 41.94 & .000 \\
\hline
\end{tabular}

The ANOVA table regarding the stepwise regression analysis showed that the described regression model was statistically significant. As can be seen in Table 5, since the stepwise regression analysis did not significantly predict the emotional commitment sub-dimension of the organizational commitment scale, it did not include the economic, social and cultural sustainability variables in the analysis and only the economic sustainability variable was treated in the stepwise regression analysis process. Managerial sustainability explains $11 \%$ of the total variance regarding emotional commitment $\left[\mathrm{F}_{(1.336)}=41.94 ; \mathrm{p}<0.001\right]$. Therefore, it may be asserted that the $\mathrm{R}^{2}$ value $\left(\mathrm{R}^{2}=.11\right)$ obtained in this analysis has a small effect size.

The stepwise regression analysis regarding continuance commitment, which is the second sub-dimension of the Organizational Commitment Scale, is presented in Table 6.

\section{Table 6}

Results of Stepwise Regression Analysis on the Prediction of Continuance Commitment

\begin{tabular}{cccccccccc}
\hline Model & $\mathrm{B}$ & Std. Error & $\beta$ & $\mathrm{t}$ & $\mathrm{p}$ & $\mathrm{R}$ & $\mathrm{R}^{2}$ & $\mathrm{~F}$ & $\mathrm{p}$ \\
\hline Constant & 2.58 & .19 & & 13.77 & .000 & & & & \\
Social S. & .149 & .05 & .16 & 2.98 & .003 & .16 & .03 & 8.91 & .003 \\
\hline
\end{tabular}

The ANOVA table regarding the stepwise regression analysis showed that the described regression model was statistically significant. As can be seen in Table 6, since the stepwise regression analysis did not significantly predict the continuance commitment sub-dimension of the organizational commitment scale, it did not include the managerial, economic and cultural sustainability variables in the analysis and only the economic sustainability variable was treated in the stepwise regression analysis process. The social sustainability sub-dimension explains about $3 \%$ of the total variance regarding continuance commitment $\left[\mathrm{F}_{(1.336)}=8.91 ; \mathrm{p}<0.01\right.$. Therefore, it may be asserted that the $\mathrm{R}^{2}$ value $\left(\mathrm{R}^{2}=.03\right)$ obtained in this analysis has a small effect size. 
The stepwise regression analysis regarding the normative commitment, which is the third sub-dimension of the Organizational Commitment Scale, is presented in Table 7.

\section{Table 7}

Results of Stepwise Regression Analysis on the Prediction of Normative Commitment

\begin{tabular}{cccccccccc}
\hline Model & B & Std. Error & $\beta$ & $\mathrm{t}$ & $\mathrm{p}$ & $\mathrm{R}$ & $\mathrm{R}^{2}$ & $\mathrm{~F}$ & $\mathrm{p}$ \\
\hline Constant & 2.09 & .18 & & 11.56 & .000 & & & & \\
Managerial S. & .30 & .04 & .36 & 7.00 & .000 & .36 & .13 & 49.07 & .000 \\
\hline Constant & 2.01 & .183 & & 10.97 & .000 & & & & \\
Managerial S. & .16 & .077 & .20 & 2.10 & .037 & & & & \\
Social S. & .16 & .078 & .19 & 2.10 & .037 & .372 & .14 & 26.97 & .000 \\
\hline
\end{tabular}

The ANOVA table regarding the stepwise regression analysis showed that the described regression model was statistically significant. As can be seen in Table 7, the stepwise regression analysis did not analyze the economic sustainability and cultural variable since it did not significantly predict the normative commitment sub-dimension of the organizational commitment scale; managerial sustainability and social sustainability variables were treated in the stepwise regression analysis process. Normative commitment sub-dimension explains $13 \%$ of the total variance regarding managerial sustainability $\left[\mathrm{F}_{(1.336)}=49.07 ; \mathrm{p}<0.001\right]$. With the addition of the social sustainability sub-dimension to the analysis, the total variance explained regarding the normative commitment increased to $14 \%\left[\mathrm{~F}_{(2.335)}=26.97 ; \mathrm{p}<0.001\right]$. When standardized regression coefficients are examined, normative commitment is found to be firstly significantly predicted by managerial sustainability sub-dimension $(\beta=.20)$, and secondly by social sustainability sub-dimension $(\beta=.19)$. It may be asserted that the $\mathrm{R}^{2}$ value found $\left(\mathrm{R}^{2}=.14\right)$ has a small effect size.

The stepwise regression analysis regarding the overall Organizational Commitment scale is presented in Table 8 .

\section{Table 8}

Results of Stepwise Regression Analysis on the Prediction of Organizational Commitment Scale (Overall)

\begin{tabular}{cccccccccc}
\hline Model & $\mathrm{B}$ & Std. Error & $\beta$ & $\mathrm{t}$ & $\mathrm{p}$ & $\mathrm{R}$ & $\mathrm{R}^{2}$ & $\mathrm{~F}$ & $\mathrm{p}$ \\
\hline Constant & 2.47 & .13 & & 19.46 & .000 & & & & \\
Managerial S. & .223 & .03 & .38 & 7.49 & .000 & .38 & .14 & 56.16 & .000 \\
\hline Constant & 2.41 & .13 & & 18.74 & .000 & & & & \\
Managerial S. & .12 & .05 & .21 & 2.26 & .025 & & & & \\
Social S. & .12 & .06 & .20 & 2.22 & .027 & .40 & .16 & 30.88 & .000 \\
\hline
\end{tabular}

The ANOVA table regarding the stepwise regression analysis showed that the described regression model was statistically significant. As can be seen in Table 8, the stepwise regression analysis did not analyze the economic and cultural sustainability analysis since it did not significantly predict the organizational commitment scale; managerial and social sustainability variables were treated in the stepwise regression 
analysis process. Managerial sustainability sub-dimension explains $14 \%$ of the total variance regarding the overall organizational commitment scale $\left[\mathrm{F}_{(1.336)}=56.16\right.$; $\mathrm{p}<0.001]$. With the addition of the social sustainability sub-dimension to the analysis, the total variance explained regarding the overall organizational commitment scale increased to $16 \%\left[\mathrm{~F}_{(2.335)}=30.88 ; \mathrm{p}<0.001\right]$. When standardized regression coefficients were analyzed, volunteer active participation was found to be significantly predicted by managerial sustainability sub-dimension in the first place $(\beta=.21)$, and by social sustainability sub-dimension in the second place $(\beta=.20)$. It may be asserted that the $\mathrm{R}^{2}$ value found $\left(\mathrm{R}^{2}=.16\right)$ has a small effect size.

\section{Conclusions}

The research findings showed that, teachers' perceptions regarding school principals' sustainable leadership behaviors are at a high level. In his study, Cayak (2018) found that teachers' perceptions regarding the sustainable leadership behaviors of school principals were at a high level. Another finding of the research is that teachers' job satisfaction levels and organizational commitment levels are high. Teachers' job satisfaction is very important both for them and for the educational institutions they work for. Teachers' job satisfaction level will directly affect the quality and thus the efficiency of the service provided (Basaran \& Guclu, 2018). Also as stated by Nacar and Demirtas (2017), organizational commitment is crucial for school employees to devote their skills and energies to the success of the school since the high level of teachers' organizational commitment will increase efficiency and quality.

In the study, the effect of school principals' sustainable leadership behaviors on teachers' job satisfaction and organizational commitment were examined. As a result of the stepwise regression analyses conducted, it was found that only the economic sustainability sub-dimension of the sustainable leadership scale significantly predicted teachers' overall job satisfaction and the intrinsic satisfaction sub-dimension of the job satisfaction scale and that only the managerial sustainability sub-dimension significantly predicted the extrinsic satisfaction sub-dimension. Such a finding reached in the research is quite meaningful. Indeed, intrinsic satisfaction comprises success, recognition, responsibility, progress, growth and the job itself. As for extrinsic job satisfaction, it includes wage, job security, working conditions, supervision and interpersonal relationships (Herzberg, 1987). Therefore, a teacher who is within the scope of intrinsic job satisfaction succeeds in his/her job, fulfils his/her instructional responsibilities and as a result becomes a teacher who is respected and recognized by his/her environment depends on whether she/he performs his/her job efficiently. In this regard, it is important to increase the technical and physical facilities of the school and to equip the teachers with materials that they can use in the education process (Isık, 2004; Akbaba \& Turhan, 2016). Since meeting these needs will require a certain cost, it is thought that the school principals' economic sustainability will contribute positively to this process. On the other hand, practices related to extrinsic job satisfaction such as improving the working conditions of teachers, conducting their professional supervision effectively, and ensuring the job security of teachers are also closely related to school administrators' managerial activities (Okutan, 2000; Akcay \& Basar, 2004; Balyer, 2012). For this reason, administratively sustainable practices of school principals are thought to have an impact on the extrinsic satisfaction of teachers. 
Finally, it was found in the research that only the economic sustainability subdimension of the sustainable leadership scale significantly predicted teachers' emotional commitment, that social sustainability sub-dimension significantly predicted the continuance commitment sub-dimension and that both managerial and social sustainability sub-dimensions significantly predicted organizational commitment scale. Emotional commitment is the individual's continuing to work in an organization because she/he wants to. Employees with high emotional organizational commitment want to continue their organizational membership because the organization's values, goals and initiatives overlap with the opinions of employees (Posey, Roberts, \& Lowry, 2015).

In the intrinsic satisfaction variable, it is thought that the educational opportunities offered by the school to teachers while they are performing their profession led them to have a desire to work in that particular school, in other words, to feel emotional commitment. On the other hand, continuance commitment is a situation in which an employee has to work in the organization for different reasons. Employees with a strong continuance commitment continue to work in the same organization because they think there is a high replacement cost in relation to job switch (Imran \& Binti Aziz, 2017). Therefore, it is thought that the social structure that the school principal will establish and the social activities she/he will create in order to get efficiency from teachers who feel a compulsory attachment to the institution they work in positively affect their commitment to their organizations. On the other hand, normative commitment is a person's showing commitment because she/he feels gratitude for the organization she/he works for. Employees with high normative commitment continue their membership in the organization if they deem it necessary (Meyer \& Allen, 1997). In normative commitment, employees continue working because of an obligation they feel due to the things the organization has offered them over time. Therefore, the commitment of employees in such a situation to their organizations is not as strong as their emotional commitment, but stronger than continuance commitment. From this point of view, it is meaningful that both the managerial and social practices of the school principal on teachers with high normative commitments significantly predict normative commitment. Eryesil and Iraz (2017), in the study they conducted on bank employees, found a significant relationship between employees' normative commitment and their managerial leadership perceptions. In addition, more research has revealed that there is a strong relationship between the leadership styles of managers and the organizational commitment of employees (Rowden, 2000; Batmunkh, 2011; Serin \& Buluc, 2012; Demirtas \& Sama, 2016). On the other hand, it is reported that the organizational socialization experiences of individuals regarding both their past (familial/cultural socialization) and the period starting from the time they became members of the organization were effective in the development of normative commitment (Allen \& Meyer, 1990; Meyer, Stanlay, Herscovitch, \& Topolnytsky, 2002).

\section{Recommendations}

Based on the results obtained from the research, the following recommendations can be made to the researchers and practitioners; (i) a similar study can be carried out at different education levels; (ii) a study can be conducted on other educational stakeholders, such as parents or students, other than teachers, using similar variables; (iii) using qualitative or mixed research methods, more in-depth knowledge can be obtained about the research subject; (iv) in-service training on sustainable leadership can be given to 
school principals in order to develop their sustainable leadership behaviors; (v) principals can organize social activities in their schools to increase social sustainability and take care to improve social relations.

\section{References}

Agarwa, P., \& Sajid, S. M. (2017). A study of job satisfaction, organizational commitment and turnover intention among public and private sector employees. Journal of Management Research, 17(3), 123-136.

Akar, H. (2018). A meta-analytic study concerning the effect of educational stakeholders' perceptions of quality of work life on their job satisfaction and organizational commitment. International Online Journal of Educational Sciences, 10(3), 101115.

Akbaba, A., \& Turhan, M. (2016). Investigating teachers' views about physical problems of primary schools (VAN Sample). Karadeniz Technical Unversity Institute of Social Sciences Journal of Social Sciences, 6(12), 341-357.

Akcay, C., \& Basar, M. A. (2004). Elementary school principals' time allocation for administrative tasks and attributed importance. Educational Administration: Theory and Practice, 38, 170-197.

Akyar, B. C., \& Sapsaglam, Ö. (2019). The effects of pre-schoolers' media usage habits on their daily life and sustainability. Discourse and Communication for Sustainable Education, 10(2), 112-128.

Allen, N. J., \& Meyer, J. P. (1990). The measurement and antecedents of affective, continuance and normative commitment to the organization. Journal of occupational psychology, 63(1), 1-18.

Allen, N. J., \& Meyer, J. P. (2000). Construct validation in organizational behavior research: The case of organizational commitment. In Problems and solutions in human assessment (pp. 285-314). Springer, Boston, MA.

Avery, G. C., \& Bergsteiner, H. (2011). Sustainable leadership practices for enhancing business resilience and performance. Strategy and Leadership, 39(3), 5-15.

Baba, M. M. (2017). Emotional intelligence, organizational commitment, and job satisfaction: A study of higher learning institutions. Amity global business review, 12(2), 51-60.

Balci, A. (2010). Glossary of explanatory educational management terms. Ankara: Pegem Press.

Balyer, A. (2012). Changing roles of contemporary school principals. Journal of Kirsehir Education Faculty, 13(2), 75-93.

Banjarnahor, H., Hutabarat, W., Sibuea, A. M., \& Situmorang, M. (2018). Job satisfaction as a mediator between directive and participatory leadership styles toward organizational commitment. International Journal of Instruction, 11(4), 869-888.

Basaran, M., \& Guclu, N. (2018). Analyzing the relationship between school principles' management styles and teachers' job satisfaction. Gazi University Journal of Gazi Education Faculty, 38(3), 949-963.

Batmunkh, M. (2011). The relationship between leader styles and organizational commitment and organizational silence and a research. Master Thesis. Marmara University Institute of Social Sciences, İstanbul. 
Baycan, A. (1985). An analysis of several aspects of job satisfaction between different occupational groups. Master Thesis. Bogazici University Institute of Social Sciences, İstanbul, Turkey.

Bilyalov, D. (2018). Organizational socialization and job satisfaction of faculty at Nazarbayev University in Kazakhstan. European Education, 50(3), 229-248.

Blackburn, B. R., \& Williamson, R. (2018). Leading change in your school: A sustainable process. Australian Educational Leader, 40(1), 8.

Borland, H., Ambrosini, V., Lindgreen, A., \& Vanhamme, J. (2016). Building theory at the intersection of ecological sustainability and strategic management. Journal of Business Ethics, 135(2), 293-307.

Buyukozturk, S. (2011). Sosyal bilimler icin veri analizi el kitabı [Manual of data analysis for social sciences]. Ankara: Pegem Publishing.

Can, A. (2014). SPSS ile bilimsel arastırma surecinde nicel veri analizi [Quantitative data analysis in scientific research process with SPSS]. Ankara: Pegem Publishing.

Casserley, T., \& Critchley, B. (2010). A new paradigm of leadership development. Industry and Commercial Training, 42(6), 287-295.

Cayak, S. (2018). Examination of sustainable leadership behaviors of school principals: A mixed method research. Doctoral dissertation. Marmara University, İstanbul.

Cayak, S., \& Cetin, M. (2018). Sustainable leadership scale: Validity and reliability study. Electronic Turkish Studies, 13(11),1561-1582.

Cetin, M., \& Cayak, S. (2018). Sustainable leadership. Ankara: Nobel Publishing.

Chen, J., \& Silverthorne, C. (2005). Leadership effectiveness, leadership style and employee readiness. Leadership \& Organization Development Journal, 26(4), 280-288.

Cohen, S. A., DeFrancia, K. L., \& Martinez, H. J. (2016). A positive vision of sustainability. Journal of Environmental Studies and Sciences, 6(1), 231-238.

Collie, R. J., Granziera, H., \& Martin, A. J. (2018). Teachers' perceived autonomy support and adaptability: An investigation employing the job demands-resources model as relevant to workplace exhaustion, disengagement, and commitment. Teaching and Teacher Education, 74, 125-136.

Daglı, A., Elcicek, Z., \& Han, B. (2018). Adaptation of organizational commitment scale to Turkish: Validity and reliability study. Electronic Journal of Social Sciences, 17(68), 1765-1777.

Davies, B. (2007). Developing sustainable leadership. Sage: Paul Chapman Publishing.

Eccles, R. G., Ioannou, I., \& Serafeim, G. (2012). The impact of a corporate culture of sustainability on corporate behavior and performance. NBER Working Paper No. 17950. http://www.nber.org/papers/w17950.pdf

Ehnert, I., Harry, W., \& Zink, K. J. (2014). Sustainability and HRM. In Sustainability and human resource management (pp. 3-32). Springer, Berlin Heidelberg.

Eryesil, K., \& İraz, R. (2017). Investigation of the relationship between leadership styles and organizational commitment a field study. Journal of Selcuk University Social Sciences Vocational School, 20(2), 129-139.

Eskici, M. (2019). Sustainable learning levels of high school students. Discourse and Communication for Sustainable Education, 10(1), 63-80.

Frese, M., \& Fay, D. (2000). Personal initiative: An active performance concept for work in the $21^{\text {st }}$ century. Research in Organizational Behavior, 23, 133-87.

George, D., \& Mallery, M. (2003). Using SPSS for Windows step by step: A simple guide and reference. Boston, MA: Allyn \& Bacon. 
Gerard, L., McMillan, J., \& D’Annunzio-Green, N. (2017). Conceptualising sustainable leadership. Industrial and Commercial Training, 49(3),116-126.

Ghosh, K., \& Chatterjee, S. R. (2014). Global mindset: Organizational consciousness and sustainable leadership: The new path of corporate excellence. AFBE Journal, $7(2), 162-172$.

Hargreaves, A., \& Fink, D. (2006). Sustainable leadership. San Francisco, CA: Jossey-Bass. Hargreaves, A., \& Fink, D. (2003). The seven principles of sustainable leadership. http://jotamac.typepad.com/jotamacs_weblog/files/seven_principles.pdf

Harris, J. M. (2000). Basic principles of sustainable development. Medford, MA: Global Development and Environment Institute, Tufts University.

Heasly, B., Iliško, Dz., Salīte, I., \& Lindner, J. (2020). The value of process and pedagogy through the sustainability prism. Discourse and Communication for Sustainable Education, 11(2), 1-4. https://doi.org/10.2478/dcse-2020-0014

Herzberg, F. (1987). One more time: How do you motivate employees? http://myfy. foundationyear.com/_upload/subjects/3/howtomotivate.pdf

Hussain, S., \& Soroya, S. H. (2017). Exploring the factors affecting job satisfaction of paraprofessional staff working in University Libraries of Pakistan. Library Review, $66(3), 144-162$.

Iliško, D. (2007). Teachers as agents of societal change. Journal of Teacher Education for Sustainability, 7(1), 14-26.

Imran, M., \& Binti Aziz, A. (2017). Religiosity and organizational commitment: A conceptual framework. International Journal of Management and Accounting Economics, 4, 953-61.

Isık, H. (2004). Ogrenme Ortamlarının Fiziksel Duzeni, Sınıf Yonetimi [Physical order of learning environments, classroom management]. Ankara: Pegem Publishing.

Jahanshahi, A. A., \& Brem, A. (2017). Sustainability in SMEs: Top management teams behavioral integration as source of innovativeness. Sustainability, 9(10), 1899.

Jaramillo, F., Mulki, J. P., \& Marshall, G. W. (2005). A meta-analysis of the relationship between organizational commitment and salesperson job performance: 25 years of research. Journal of Business Research, 58(6), 705-714.

Kalaycı, S. (2010). Spss Uygulamalı Cok Degiskenli İstatistik Teknikleri [Multi-variable statistical techniques with SPSS applied]. Ankara: Asil Publishing.

Kaul, S., \& Singh, A. (2017). Organisational justice as an enhancer of organisational commitment. The International Journal of Indian Psychology, 4(2/89), 52-70.

Kelidbari, H. R., Dizgah, M. R., \& Yusefi, A. (2011). The relationship between organization commitment and job performance of employees of Guilan Province social security organization. Interdisciplinary Journal of Contemporary Research in Business, 3(6), 555-568.

Kennerly, S. M. (1989). Leadership behavior and organizational characteristics: Implications for faculty satisfaction. Journal of Nursing Education, 28(5), 198-202.

Kunnan, A. J. (1998). An introduction to structural equation modelling for language assessment research. Language Testing, 15(3), 295-332.

Leithwood, K. A., \& Seashore-Louis, K. (2011). Linking leadership to student learning. San Francisco, CA: Jossey Bass Ltd.

Lizote, S. A., Verdinelli, M. A., \& Nascimento, S. D. (2017). Organizational commitment and job satisfaction: A study with municipal civil servants. Revista de Administracão Pública [Public Administration Review], 51(6), 947-967. 
McCann, J., \& Sweet, M. (2014). The perceptions of ethical and sustainable leadership. Journal of Business Ethics, 121(3), 373-383.

Meyer, J. P., \& Allen, N. J. (1991). A three-component conceptualization of organizational commitment. Human Resource Management Review, 1(1), 61-89.

Meyer, J. P., \& Allen, N. J. (1997). Commitment in the workplace: Theory, research, and application. Thousand Oaks, CA: Sage.

Meyer, J. P., Allen, N. J., \& Smith, C. A. (1993). Commitment to organizations and occupations: Extension and test of a three-component conceptualization. Journal of Applied Psychology, 78, 538-551.

Meyer, J. P., Stanley, D. J., Herscovitch, L., \& Topolnytsky, L. (2002). Affective, continuance, and normative commitment to the organization: A meta-analysis of antecedents, correlates, and consequences. Journal of vocational behavior, 61(1), 20-52.

Mourkogiannis, N. (2005). The realist's guide to moral purpose. Strategy+Business, 41, 1-2. http://www.strategy-business.com/article/05405 ?gko=fea $8 \mathrm{f}$

Mowday, R. T., Steers, R. M., \& Porter, L. W. (1998). Reflections on the study and relevance of organizational commitment. Human Resource Management Review, $8(4), 387-401$.

Munir, H., \& Iqbal, M. Z. (2018). A study of relationship between leadership styles of principals and job satisfaction of teachers in colleges for women. Bulletin of Education and Research, 40(2), 65-78.

Nacar, D., \& Demirtas, Z. (2017). Organizational commitment level of high school teachers. International Journal of Turkish Education Sciences, 9, 547-558.

Northouse. (2007). Leadership theory and practice ( $3^{\text {rd }}$ Ed.). London: Sage publication, rezaInc.

Okutan, M. (2000). Evaluation of the managerial behavior of school principals. Pamukkale University Journal of Education, 7, 162-167.

Ozsoy, S., \& Ozsoy, G. (2013). Effect size reporting in educational research. Elementary Education Online, 12(2), 334-346.

Patrick, A. S. (2007). Examination of teacher workplace satisfaction and student achievement. Doctoral dissertation at the Georgia Southern University.

Posey, C., Roberts, T. L., \& Lowry, P. B. (2015). The impact of organizational commitment on insiders' motivation to protect organizational information assets. Journal of Management Information Systems, 32(4), 179-214.

Reza, O. (2013). Leadership style, organizational commitment and job satisfaction - a case study on high school principals in Tehran Iran. American Journal of Humanities and Social Sciences, 1(4), 263-267.

Rezaee, A., Khoshsima, H., Zare-Bahtash, E., \& Sarani, A. (2018). A mixed method study of the relationship between EFL teachers' job satisfaction and job performance in Iran. International Journal of Instruction, 11(4), 577-592.

Rowden, R. W. (2000). The relationship between charismatic leadership behaviors and organizational commitment. Leadership and Organization Development Journal, 21(1), 30-35.

Salīte, I., Drelinga, E., Iliško, D., Oḷehnoviča, E., \& Zariņa, S. (2016). Sustainability from the transdisciplinary perspective: An action research strategy for continuing education program development. Journal of Teacher Education for Sustainability, 18(2), 135-152. 
Salīte, I., Fjodorova, I., Iliško, Dz., Ivanova, O., \& Meihami, H. (2020). JTES for sustainable development: An action research environment for the development and sustainable future of the journal identity. Journal of Teacher Education for Sustainability, 22(1), 1-5. doi: 10.2478/jtes-2020-0001

Schwalb, P. G. (2011). Sustainability leader competencies: A grounded theory study. (Doctoral dissertation.). University of Nebraska, Nebraska, ABD.

Serin, M. K., \& Buluc, B. (2012). The relationship between instructional leadership and organizational commitment in primary schools. Educational Administration: Theory and Practice, 18(3), 435-459.

Spector, P. E. (1997). Job satisfaction: Application, assessment, cause, and consequences. Thousand Oaks, Calif: Sage Publications.

Tepayakul, R., \& Rinthaisong, I. (2018). Job satisfaction and employee engagement among human resources staff of Thai private higher education institutions. The Journal of Behavioral Science, 13(2), 68-81.

Weiss, D. J., Dawis, R. V., England, G. W., \& Lofquist, L. H. (1967). Manual for the Minnesota Satisfaction Questionnaire: Minnesota studies in vocational rehabilitation. Minneapolis: Industrial Relations Center, University of Minnesota.

Yazıcıoglu, Y., \& Erdogan, S. (2004). SPSS Uygulamalı bilimsel arastırma yontemleri [SPSS Applied scientific research methods]. Ankara: Detay Publishing.

Yousef, D. A., (2000). Organizational commitment: A mediator of the relationships of leadership behavior with job satisfaction and performance in a non-western country. Journal of Managerial Psychology, 15(1), 6-24.

Zeynel, E. (2014). A study on the relationships among occupational motivation, job satisfaction and organizational commitment aimed at academicians. (Doctoral dissertation.). Suleyman Demirel University, Isparta, Turkey.

Correspondence concerning this paper should be addressed to Semih Çayak, Kaynarca Mah. Dönemec Sok. Nr.9 D 4 Pendik, Turkey. Email: semihcayak@gmail.com 